Check for updates

Cite this as: $B M J 2022 ; 376: 0482$ http://dx.doi.org/10.1136/bmj.0482

Published: 23 February 2022

\section{Don't worry about the drug industry's profits when considering a waiver on covid-19 intellectual property rights}

This article (BMJ 2022;376:e067367, doi:) has been updated online to correct an error: The global drug industry's share of total net profits made by all companies listed on the stock market rose from around 3\% in the mid-1970s to a staggering $10 \%$ at its peak in the early 2000 s, not 2020 s as previously stated. 